\title{
History of cerebral localization and the emigration plight of three neuroscience giants from Nazi Germany: Josef Gerstmann, Adolf Wallenberg, and Franz Josef Kallmann
}

\author{
Michael Fana, MSc, ${ }^{1}$ Eleanor C. Smith, BS, ${ }^{1}$ Jessica L. Gable, BA, ${ }^{2}$ Nihal Manjila, ${ }^{3}$ and \\ Sunil Manjila, MD ${ }^{4}$ \\ ${ }^{1}$ Central Michigan University College of Medicine, Mount Pleasant, Michigan; ${ }^{2}$ Wayne State University School of Medicine, \\ Detroit, Michigan; ${ }^{3}$ Case Western Reserve University, Cleveland, Ohio; and ${ }^{4}$ Department of Neurosurgery, McLaren Bay \\ Regional Medical Center, Bay City, Michigan
}

\begin{abstract}
The Nazi regime held power for well over a decade in Germany and were steadfast in their anti-Semitic agenda. Among the massive cohort of immigrants to America were approximately 5056 Jewish physicians, including several highly esteemed neurologists and neuroscientists of the time. Emigrating to a new world proved difficult and provided new challenges by way of language barriers, roadblocks in medical careers, and problems integrating into an alien system of medical training and clinical practice. In this article, the authors examine the tumultuous and accomplished lives of three Jewish German and Austrian neurologists and neuroscientists during the time of the Third Reich who shaped the foundations of neuroanatomy and neuropsychology: Josef Gerstmann, Adolf Wallenberg, and Franz Josef Kallmann. The authors first examine the successful careers of these individuals in Germany and Austria prior to the Third Reich, followed by their journeys to and lives in the United States, to demonstrate the challenges an émigré physician faces for career opportunities and a chance at a new life. This account culminates in a description of these scientists' eponymous syndromes.

Although their stories are a testimony to the struggles in Nazi Germany, there are intriguing and notable differences in their ages, ideologies, and religious beliefs, which highlight a spectrum of unique circumstances that impacted their success in the United States. Furthermore, in this account the authors bring to light the original syndromic descriptions: Gerstmann discovered contralateral agraphia and acalculia, right-left confusion, and finger agnosia in patients with dominant angular gyrus damage; Wallenberg described a constellation of symptoms in a patient with stenosis of the posterior inferior cerebellar artery; and Kallmann identified an association between hypogonadotropic hypogonadism and anosmia based on family studies. The article also highlights the unresolved confusions and international controversies about these syndromic descriptions. Still, these unique cerebral syndromes continue to fascinate neurologists and neurosurgeons across the world, from residents in training to practicing clinicians and neuroscientists alike.
\end{abstract}

https://thejns.org/doi/abs/10.3171/2019.6.FOCUS19340

KEYWORDS Franz Josef Kallmann; Josef Gerstmann; Adolf Wallenberg; émigré physician; Jewish migration; cerebral localization

$\mathrm{W}$ ORLD War II was one of the most influential events of recent world history and the seminal event of the early to mid-1900s..$^{32}$ Approximately 6 million Jews, 250,000 people with disabilities, 200,000 Gypsies, and tens of thousands of other targeted individuals were killed during the war in concentration camps and executions. ${ }^{47}$ Furthermore, many physicians and scientists took full advantage of the opportunities to use human sub- jects to advance their research in neuroscience through the Nazi regime. In fact, Nazi Germany was responsible for 400,000 sterilizations on the premise of congenital feeblemindedness, schizophrenia, hereditary epilepsy, and other neurological illnesses. This program continued until euthanasia was deemed more appropriate for being economical and fulfilling a eugenic ideology. ${ }^{53}$ Meanwhile, numerous notable physicians such as Oskar and Cécile Vogt

ABBREVIATIONS MTS = Maria-Theresia-Schlössel.

SUBMITTED May 1, 2019. ACCEPTED June 12, 2019

INCLUDE WHEN CITING DOI: 10.3171/2019.6.FOCUS19340. 
TABLE 1. Neuroscientist physicians who emigrated from Germany or endured the Third Reich (1933-1945)

\begin{tabular}{|c|c|c|c|}
\hline \multicolumn{2}{|r|}{ Emigrated } & \multicolumn{2}{|c|}{ Remained in Homeland } \\
\hline Neuroscientist & Chief Contribution & Neuroscientist & Chief Contribution \\
\hline $\begin{array}{l}\text { Clemens Ernst Benda (1898- } \\
\text { 1975) }\end{array}$ & Down syndrome & Ludwig Pick (1868-1944) ${ }^{48}$ & Niemann-Pick disease \\
\hline Edith Jacobson (1897-1978) ${ }^{23}$ & Developed a revised drive theory & $\begin{array}{l}\text { Władysław Sterling (1877- } \\
\text { 1943) }\end{array}$ & Discovered Sterling reflex \\
\hline Erwin Strauss $(1891-1975)^{26}$ & $\begin{array}{l}\text { Pioneered anthropological medicine \& } \\
\text { psychiatry }\end{array}$ & Łucja Frey $(1889-1942)^{17}$ & $\begin{array}{l}\text { Helped describe auriculotemporal } \\
\text { nerve (Frey's syndrome) }\end{array}$ \\
\hline $\begin{array}{l}\text { Franz Josef Kallmann (1897- } \\
\qquad 1965)^{22}\end{array}$ & Kallmann syndrome & $\begin{array}{l}\text { Johannes Cassianus Pompe } \\
\quad(1901-1945)^{52}\end{array}$ & $\begin{array}{l}\text { Described glycogen storage disease } \\
\text { type II (Pompe disease) }\end{array}$ \\
\hline Franz Kramer (1878-1967) ${ }^{28}$ & Identified ADHD with Halls Pollnow & $\begin{array}{l}\text { Walther Spielmeyer } \\
\quad(1879-1935)^{24}\end{array}$ & Discovered Spielmeyer-Vogt disease \\
\hline $\begin{array}{l}\text { Friedrich Heinrich Lewy (1885- } \\
\text { 1950) }\end{array}$ & $\begin{array}{l}\text { Discovered Lewy bodies in Parkinson's } \\
\text { disease }\end{array}$ & Jules Tinel $(1879-1952)^{42}$ & Identified Tinel sign \\
\hline Josef Gerstmann (1887-1969)57 & Gerstmann syndrome & $\begin{array}{l}\text { Cécile Vogt-Mugnier } \\
\quad(1875-1962)^{27}\end{array}$ & $\begin{array}{l}\text { Collaborated with Brodmann to map } \\
\text { the cortex \& thalamus }\end{array}$ \\
\hline Hans Pollnow (1902-1943) ${ }^{28}$ & Identified ADHD with Franz Kramer & Oskar Vogt (1870-1959) ${ }^{27}$ & $\begin{array}{l}\text { Mapped the cytological \& myeloarchi- } \\
\text { tecture of the brain and the func- } \\
\text { tional anatomy of the basal ganglia }\end{array}$ \\
\hline $\begin{array}{l}\text { Hans-Lukas Teuber (1916- } \\
\qquad 1977)^{16}\end{array}$ & A founder of neuropsychology & Oskar Fischer (1876-1942) ${ }^{15}$ & $\begin{array}{l}\text { Contributed to Alzheimer's disease } \\
\text { research }\end{array}$ \\
\hline Heinz Lehmann (1911-1999) 35 & Father of modern psychopharmacology & Viktor E. Frankl (1905-1997) ${ }^{39}$ & Suicide prevention \\
\hline Kurt Goldstein (1878-1965) & Proposed principle of self-actualization & & \\
\hline $\begin{array}{l}\text { Lothar B. Kalinowsky (1899- } \\
\qquad 1992)^{45}\end{array}$ & Advocate for electroconvulsive therapy & & \\
\hline Otto Marburg (1874-1948) & $\begin{array}{l}\text { Significant contributions to neuro-oncol- } \\
\text { ogy \& to the understanding of multiple } \\
\text { sclerosis }\end{array}$ & & \\
\hline Adolf Wallenberg $(1862-1949)^{50}$ & Lateral medullary (Wallenberg) syndrome & & \\
\hline Carl Felix List (1902-1968) & Arteriography of the carotid artery & & \\
\hline
\end{tabular}

$\mathrm{ADHD}=$ attention deficit hyperactivity disorder.

took to voicing their opposition to the Nazi regime, while others fabricated passports, identification certificates, and diagnoses to save as many victims of the regime as possible. ${ }^{54}$ Roughly 2000 physicians who remained under Nazi rule were the unfortunate victims of the Holocaust..$^{55}$ Unfortunately, other physicians were victims of the Third Reich; between 4500 and 6000 physicians emigrated from Germany and were among the 78,000 Jewish immigrants from that country by 1939 (Table 1).

By the end of the 1940s, many German physicians had emigrated to the United States, particularly to New York or Boston, from Berlin. Much of this mass emigration was in response to the Law on the Re-Establishment of the Professional Civil Service implemented by the Nazi regime in April 1933, which mandated that all Jews and opponents of the Nazi Party resign any civil positions in Germany. Many of these physicians $(60 \%-75 \%)$ were Jewish, and approximately $3 \%$ of these immigrants were neurologists and psychologists. The majority had chosen New York as their destination given the laxity of its immigration laws, ease of medical licensing, and greater representation of ethnic minorities. Nonetheless, emigration to the United States was no easy feat because language, cultural, and employment barriers made transitioning to American life difficult. ${ }^{6}$ This was not unlike the story of Sigmund Freud-a Jewish-Austrian neurologist renowned for psychoanalysis, who fled Nazi Germany to take refuge in the United Kingdom, or Otto Marburg, a Viennese neurologist and colleague of Sigmund Freud, who emigrated to the United States. ${ }^{18,33}$ Unfortunately, the Jewish population after emigration to New York were reported to have suffered disparity in admission for medical training and subsequent employment in those days. This was due to quota systems imposed against Jewish medical applicants in retaliatory response to the rising number of Jewish aspirants for these positions. This was vividly depicted in The Legacy of Tracy J. Putnam and H. Houston Merritt: Modern Neurology in the United States by Lewis P. Rowland, an emeritus professor of neurology at Columbia University in New York, and Time to Heal: American Medical Education from the Turn of the Century to the Era of Managed Care by the medical historian Kenneth M. Ludmerer. ${ }^{29,40}$

We reviewed the published literature on German neuroscientists who emigrated to the United States during the Third Reich. Among this cohort were included Josef 


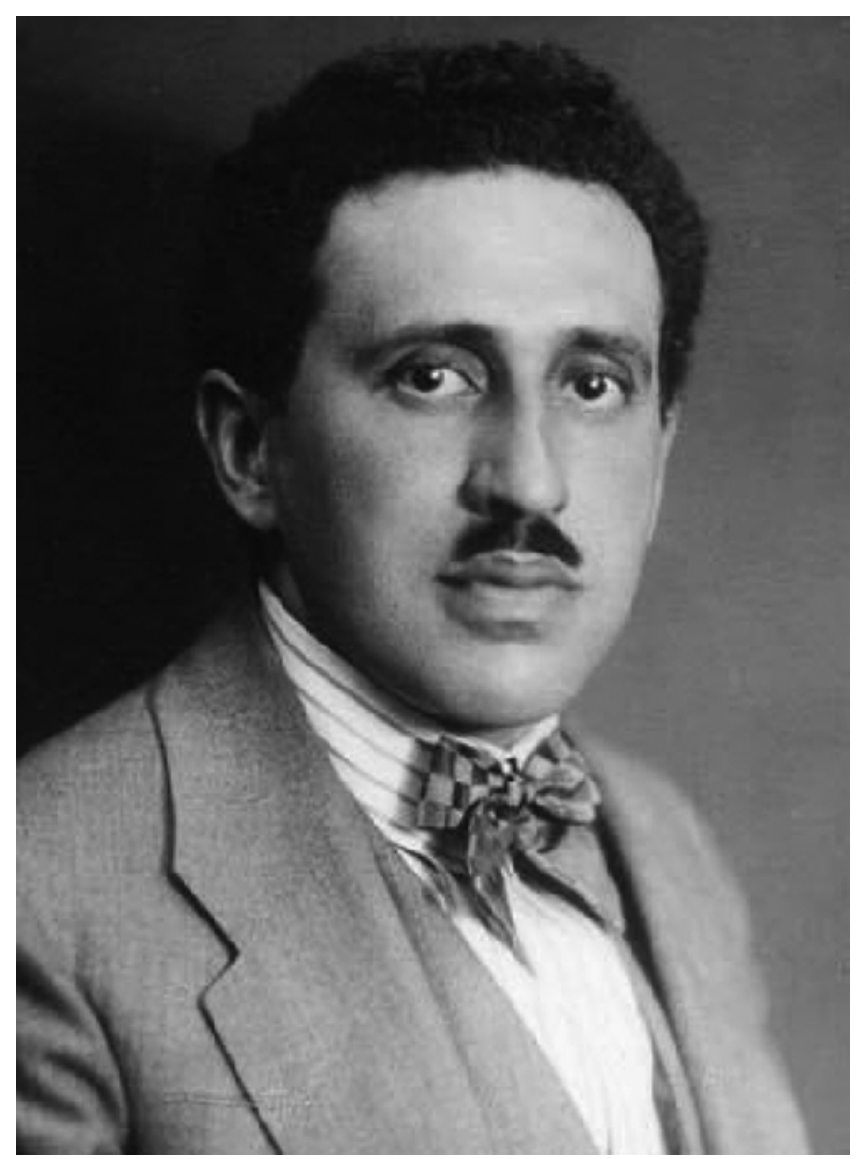

FIG. 1. Josef Gerstmann (1887-1969). Austrian-born Jewish neurologist renowned for identifying Gerstmann syndrome in a series of publications between 1924 and 1932. 8-14 Photograph circa 1930. Photographer: Max Schneider. From the Collections of the Medical University of Vienna. CC BY 1.0 (https://creativecommons.org/licenses/by/1.0/).

Gerstmann (1887-1969), Adolf Wallenberg (1862-1949), and Franz Josef Kallmann (1897-1965), who are known for their eponymous neurological syndromes. Specifically, we highlight the personal and professional life of these accomplished scientists who escaped the horrors of a Nazi-occupied Europe at the height of their careers. We further demonstrate that although the United States harbored them from the dangers of a world war, this new country was not as conducive to their research careers as their home institutions had been. ${ }^{19}$

\section{Josef Gerstmann (1887-1969)}

Josef Gerstmann (Fig. 1) was a prominent Austrian neurologist during the early 20 th century, recognized for his description of Gerstmann syndrome and GerstmannSträussler-Scheinker disease. Unfortunately, Gerstmann and his wife were forced to emigrate from their beloved home in Vienna to New York as a consequence of the Austrian annexation to Nazi Germany (Anschluss) given their pronounced Jewish faith. However, settling in New York was not as conducive to research productivity for Gerstmann..$^{46}$

Gerstmann completed medical school in 1912 at Vien- na University Medical School and continued his education in neuropathology under Heinrich Obersteiner. His career came to an initial halt with the Great War (1914-1918), during which Gerstmann served and returned a decorated veteran, which fueled his patriotism for Austria. ${ }^{46}$ Gerstmann's foothold in the academic world began when in 1918 he published and described a middle postcentral parietal lobe injury and adjacent supramarginal gyrus damage from a gunshot wound in an infantryman of the Great War. This patient presented with tactile agnosia but intact sensory modalities, stereognosis, and morphognosis. In accordance to this presentation and his knowledge of neuroanatomy, Gerstmann hypothesized that this lesion had impaired the connection between the cortex and nearby cortical structures..$^{57}$ This and many other experiences in identifying parietal lesions led Gerstmann to identify the iconic tetrad of symptoms associated with Gerstmann syndrome: contralateral agraphia and acalculia, right-left confusion, and finger agnosia in patients with dominant angular gyrus damage. His first description of finger agnosia appeared in 1924, and the remaining aspects of the iconic syndrome led to his series of publications on the matter between 1924 and 1932. ${ }^{8-14}$

In 1924, he presented the case of a 52-year-old woman with a history of a left-sided stroke, who was unable to write, calculate, or identify the fingers of the examiner or her own. Interestingly, she pointed to the ipsilateral hand when asked to and reproduced the examiner's hand movements, albeit mirror-wise. In the setting of her preserved language abilities and the knowledge of her body parts and location preserved, she was demonstrated to have a remarkable finger agnosia. Notably, Gerstmann's two new cases reported 3 years later described patients with the classic tetrad and additional findings of constructional apraxia, color anomia, and impaired number reading; this observation led to the belief that agraphia and finger agnosia were far more profound symptoms in the Gerstmann tetrad. ${ }^{9,41}$ Whenever the tetrad was found in a perfect cluster, Gerstmann thought of it as failure of a single cognitive mechanism related to the lateralized, vulnerable, and differentiated elements of the human body such as fingers, naming it "Grundstörung." Often, the cluster of Gerstmann's tetrad was not always "pure" and did not satisfy the "electivity" because it was always confounded or associated with aphasias, anomias, alexia, constructional apraxia, or right hemianopia. ${ }^{41}$

In 1956, Arthur Benton and Russell Meyers questioned the originality of the tetrad by citing French ophthalmologist, Jules Badal, who in 1888 reported a patient's inability to name and recognize fingers, with right-left confusion and agraphia as well as alexia, inaccurate sound localization, and impaired visuomotor coordination. ${ }^{1,3}$

Several scientists, such as Kinsbourne and Warrington to name a few, also refuted Gerstmann's findings that a single common functional denominator across heterogeneous cognitive operations could not explain the inconsistent constellation of his proposed syndrome..$^{25}$

Many neuroscientists considered this eponymous syndrome "a dismissed oligarchy" or an "artefact of defective and biased observation." Its authenticity has still not been settled despite advances in neuropsychological test- 


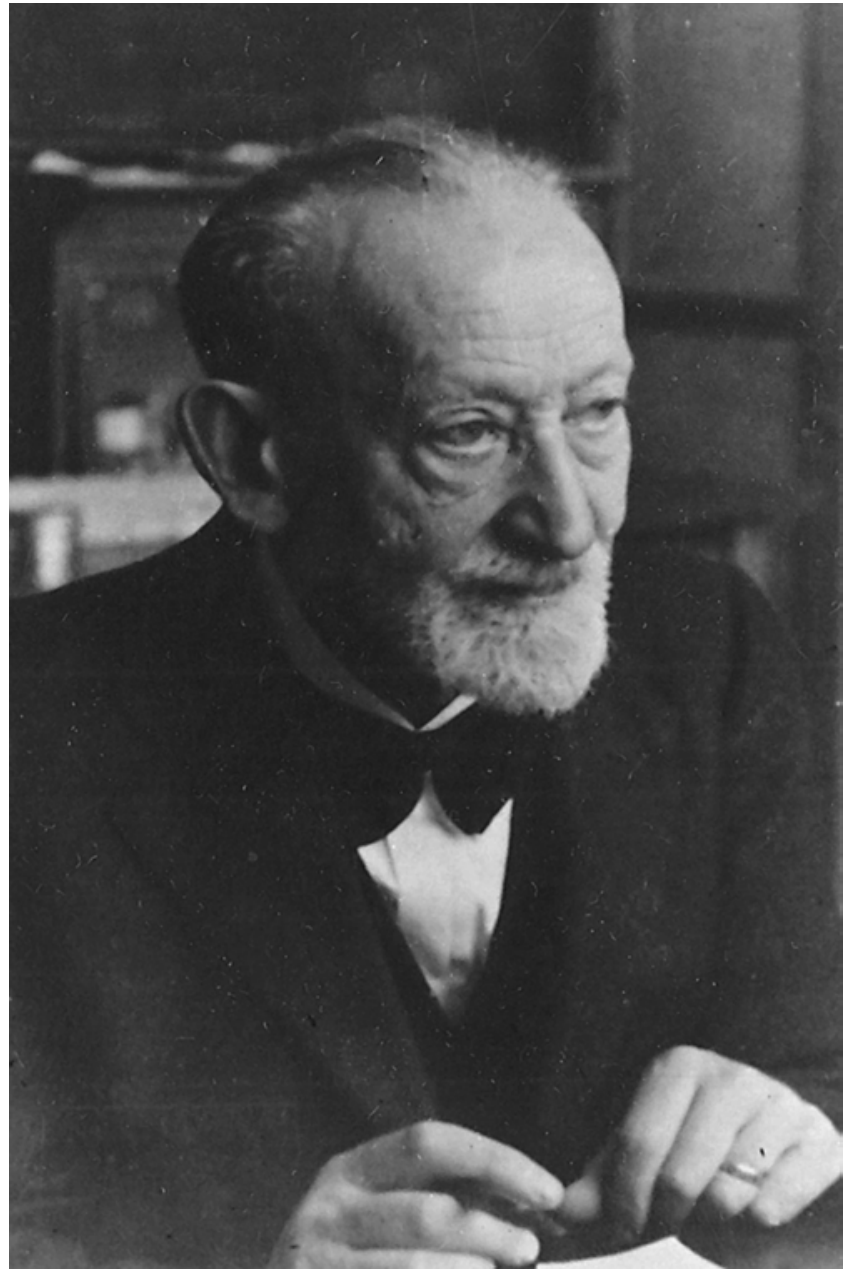

FIG. 2. Adolf Wallenberg (1862-1949). German-born Jewish neurologist notable for identifying lateral medullary syndrome in $1895 .{ }^{49}$ Reproduced with permission from Zeidman, LA: The central role of neuroscientists under National Socialism, in Tatu L, Bogousslavsky J (eds): War Neurology. Frontiers of Neurology and Neuroscience. Basel: Karger, 2016, Vol 38, pp 168-183. DOI: 10.1159/000442682. Copyright @ 2016, Karger Publishers, Basel, Switzerland.

ing batteries, functional neuroimaging studies, cortical and subcortical electrical stimulation, fiber tractography, and diffusion tensor imaging, etc. However, there are also arguments supporting a role of latent aphasia, emerging cognitive decline, developmental and cultural relations with finger agnosia, as well as the effects of intricate temporal dynamics of neuronal circuitry in the pathogenesis of Gerstmann syndrome. ${ }^{41}$

Gerstmann was also noted for his research on neurosyphilis, about which many foreign neuroscientists had traveled to Vienna to learn. Given the success of his career thus far as a research assistant to Wagner-Jauregg and later as Director at the Maria-Theresia-Schlössel (MTS) Neurological Institute (1930-1938), Gerstmann could perform and dictate research operations, which allowed him to conduct his research efficiently. Leaving behind a life of such academic success and clinical research opportunity was certainly a difficult matter that required significant deliberation during the difficult times of Nazi Germany. ${ }^{57}$ Gerstmann was noted to be a man of commitment and humility. He often spent hours more than was necessary to help his patients and lived near the hospital to have more time with his patients and research. ${ }^{57}$ Nonetheless, the academic world in Vienna did not view Jewish physicians and researchers favorably. As such, professorships and academic appointments continued to be unavailable to Jewish physicians and scientists. However, given his promising talent and expertise in research, Gerstmann was appointed head of the Neurology and Psychiatry University Clinic in 1928, and not long after, he acquired the position of Director of the Viennese MTS Neurological Institute. He was able to acquire these appointments despite the antiSemitic attitudes held by other academics and the bureaucratic enforcements. ${ }^{57}$

Although Nazi ideologies were rooted far from Vienna, they did not take long to spread rapidly abroad. The threat to livelihood became a reality on March 13, 1938, when Austria was annexed to Germany and Nazi sympathizers sprouted among the employees of the MTS Neurological Institute..$^{43}$ For Gerstmann, this change brought concerns but did not sway his mind to emigrate. It was his wife, Martha Gerstmann, who viewed the changing political climate as worrisome, and that viewpoint ultimately persuaded the couple to emigrate. Coincidentally, just prior to emigrating, Gerstmann was relieved from his job (in April 1938) and eventually closed his private practice due to heavy Nazi taxation. With the help of their American sponsor and friend, Paul Schilder, Gerstmann and his wife made their way to New York on June $14,1938 .{ }^{57}$ Gerstmann was fortunate in his timely escape from Austria because he most likely would have been one of the innumerable prisoners of the concentration camps had he not left his homeland. Luckily for him, the medical licensing board was not as strict in New York as it was in other states, and it bestowed upon Gerstmann his medical license in 1939. He secured a position as a research assistant and later as an associate at the New York Neurological Institute from 1941 until 1946 while concomitantly working as an attending neuropsychiatrist at the Presbyterian Hospital Neurology Department until 1949. For such an accomplished researcher-physician, this was a considerable step down in career advancement. ${ }^{57}$

Although Gerstmann continued to publish work on neurosyphilis and body image disorders upon arriving in New York, he would never again reach the heights of the research magnate he once was in Vienna. Eventually Gerstmann established a private clinic at his home, where he would see patients until his death in 1969. Like many of the other 2000 Austrian Jewish physicians and scientists of his time, Gerstmann's life is a true testament to the challenges of emigration, even for the highest-caliber academic. In his lifetime, Gerstmann published more than 100 papers, yet only 7 were published after the annexation of Austria to Nazi Germany and his emigration to New York..$^{57}$

\section{Adolf Wallenberg (1862-1949)}

Adolf Wallenberg (Fig. 2) was a prominent neurologist who was most notable for describing Wallenberg 
syndrome. The delineation of this syndrome was a truly remarkable accomplishment for his time and a testament to his strong understanding of neuroanatomy and his impeccable clinical examination skills. Wallenberg was born in Danzig, Germany, where he obtained his medical education with his first notable work in cerebral palsy as described in his doctoral dissertation. Soon after that he established a medical clinic in 1885 , and many years later, from 1907 until 1927, operated as Chief of Internal Medicine and Psychiatry at Danzig City Hospital. Thereafter, Wallenberg continued to see patients at his clinic because of his love of medicine and care for his patients, many times not charging poor patients for service. ${ }^{44}$ Wallenberg's career was quite fruitful with a total of 67 publications to his name. Of greatest importance was his description of lateral medullary syndrome, which he described in his paper "Akute Bulbäraffektion" (1895) as an acute bulbar lesion in a patient who came to him for a host of symptoms, namely: loss of pain and temperature sensation, anesthesia of the left half of the face, hyperesthesia of the left half of the body, swallow paralysis, absent patellar reflexes, and absent cremaster reflex, among many other symptoms in the months that followed..$^{49}$ This same patient died 5 years later, and Wallenberg's autopsy report confirmed his suspected lesion localization as a 2-cm occlusion and stenosis of the posterior inferior cerebellar artery. This led to his subsequent publication classifying this constellation of findings as Wallenberg syndrome in $1901 .^{50}$

Wallenberg also faced controversies about the originality of describing the lateral medullary syndrome. In 1810, Gaspard Vieusseux, a Genevan physician, described at the Medical and Chirurgical Society of London a patient with a lateral medullary infarction who presented with the following constellation of symptoms: vertigo, unilateral facial numbness, loss of pain and temperature sensation in opposite limbs, dysphagia and hoarseness, minor tongue involvement, drooping eyelids, and hiccups. ${ }^{31}$ Yet, Wallenberg's clinical description and exact lesion localization was more encompassing of the complex syndrome. Moreover, Wallenberg had published 15 cases with the exact syndrome symptoms and localization by $1922 .{ }^{51}$

Wallenberg had specifically studied the role of the posterior inferior cerebellar artery and the complex symptoms of lateral medullary syndrome. As we now understand, the ipsilateral cerebellar signs including ataxia, dysmetria (past pointing), and dysdiadochokinesia occur due to inferior cerebellar peduncle involvement, whereas the contralateral reduction in pain and temperature sensation from the body (limbs and torso) occur due to lateral spinothalamic tract involvement; the classic palatal myoclonus develops due to involvement of the central tegmental tract; the ipsilateral deficits in pain and temperature sensation from the face are attributed to the spinal trigeminal nucleus and tract; the severe vertigo occurs within Deiter's nucleus, which in turn contributes to ataxia; the descending sympathetic fibers are responsible for ipsilateral Horner's syndrome; and finally, damage to the nucleus ambiguus of the vagus nerve and glossopharyngeal nerve results in ipsilateral laryngeal, pharyngeal, and palatal hemiparalysis leading to dysphagia, hoarseness, and absence of the gag reflex.
Wallenberg retired from his position as Chief in Danzig City Hospital and in 1929 received the Erb Medal at the meeting of the German Neurological Society for his work in neuroanatomy, neurophysiology, and neuropathology. ${ }^{56}$ Unfortunately, it was not long before May of 1933 when the Nazi regime established its foothold in Danzig. Danzig quickly became a violent and terrorizing city for the Jews a year later, culminating in severe brutality against the Jews and destruction of their properties, businesses, and synagogues in 1938. In 1941, only 600 Jews remained in Danzig of the approximately 10,000 Jewish residents once settled there. Unfortunately, the remaining Jews still residing in Danzig were eventually sent to Warsaw or Theresienstadt concentration camps by March 1941 when emigration was halted by the Nazis. ${ }^{21}$ Wallenberg endured much of these changes, having been forced from his home and clinic in 1934, until eventually losing his right to practice, research, and work in 1938 for being Jewish. Miraculously, Wallenberg managed to escape from Danzig just 3 days before the Blitzkrieg of Poland by Germany in August of $1939 .{ }^{56}$ Sir Wilfrid Le Gros Clark at Oxford University sponsored Wallenberg and his wife for emigration to England, where they spent considerable time during the war. However, in 1941 they relocated to Chicago to join their daughter. At this stage in his life, Wallenberg continued with lectures on neuroanatomy and neurophysiology, and provided consultations on cases before dying from a myocardial infarction and heart block at the age of $86 . .^{56}$

\section{Franz Josef Kallmann (1897-1965)}

Franz Josef Kallmann (Fig. 3) was a neuropsychiatrist who obtained his medical degree in 1919 and worked under psychiatrist Karl Bonhoeffer in Berlin and Ernst Ruedin in Munich. In 1936, he moved to the United States to work at the Psychiatry Department at Columbia University's Medical School. Kallmann, although known for describing Kallmann syndrome, interestingly devoted much of his career to research schizophrenia and its genetic basis. He was a major proponent of eugenics and demonstrated the inheritance pattern of schizophrenia with studies in twins. Although he had great influence in Berlin with his research on genetic differences between peoples, it was not readily accepted by the prevailing views of clinical psychiatry in America. This was due in part to the recent Nazi atrocities disguised under the premise of genetic differences and was only later accepted in the 1960s, shortly before his death. ${ }^{2}$

Although Kallmann is credited with reporting his eponymous syndrome, it was Spanish physician-scientist, Aureliano Maestre de San Juan, who first discovered in 1856 what would later be described as Kallmann syndrome. ${ }^{30}$ Maestre de San Juan had described in his autopsy report a man with an underdeveloped penis and testes, anorchia, and absent olfactory bulbs with subsequent anosmia. ${ }^{4}$ In 1934, Kallmann identified Kallmann syndrome as a genetic condition caused by the failure to begin or complete puberty along with anosmia or hyposmia. He later published his findings in 1944 on his studies of the association between hypogonadism and anosmia in three families and highlighted the hereditary basis of the syndrome. ${ }^{22}$ Several 


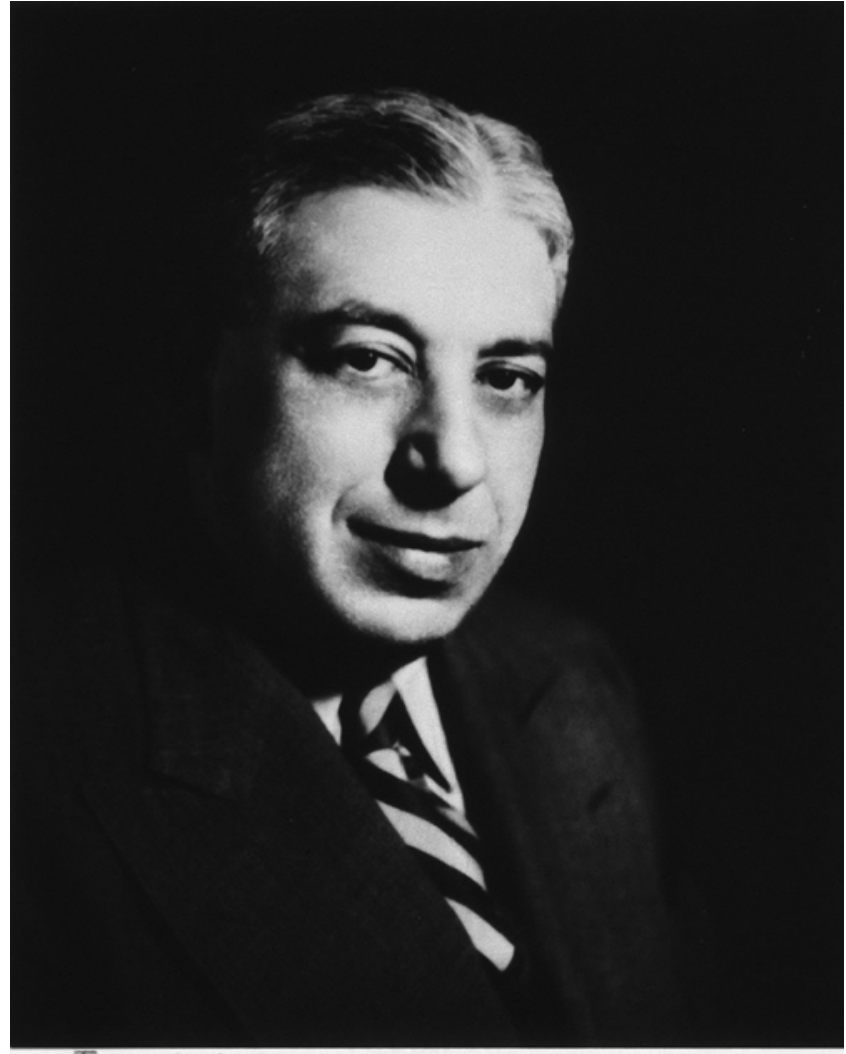

Fiant krollonams

FIG. 3. Franz J. Kallmann (1897-1965). German-born Jewish neuropsychiatrist renowned for identifying Kallmann syndrome in 1934 with significant contributions to research in schizophrenia. ${ }^{22,38}$ Photograph 1950. Public domain. From the National Library of Congress Digital Collections. Contributed by Columbia University. NLM Image ID No. B015776 (http://resource.nlm.nih.gov/101420182).

decades later in 1971, Naftolin et al. identified the source of the hypogonadotropic hypogonadism as a deficiency in gonadotropin-releasing hormone $(\mathrm{GnRH}) .{ }^{34}$

Franz Josef Kallmann was the son of Marie and Bruno Kallmann and of Jewish faith. He served in the German army during World War I and upon returning home, Kallmann received his Doctor of Medicine in 1919 at the University of Breslau. Thereafter, he continued his studies with psychiatrist Karl Bonhoeffer at the Charité Hospital. Between 1928 and 1935 in Berlin, his research in schizophrenia took roots alongside Ruedin in Munich as part of the Munich German Research Institute for Psychiatry. ${ }^{37}$ Kallmann's work in schizophrenia contributed to his favorable outlook on the application of eugenics in society, one that echoed the sentiments of the Nazi regime in greater magnitude. In fact, Kallmann is noted to have believed that the eugenic policies of his time were too soft for what was necessary to avoid the schizophrenic patients who "crowd mental hospitals all over the world, but also afford, to society as a whole, an unceasing source of maladjusted cranks, asocial eccentrics and the lowest types of criminal offenders." 37

Emigration to the United States was difficult for Kallmann, especially given that his Jewish faith was only held by birth and not by current personal belief or practice. However, Kallmann was fortunate in his securement of a letter of recommendation from Dr. Karl Johann PetersenBerstel to Franz Boas, a German-American anthropologist at Columbia University. Although this facilitated Kallmann's emigration, he was afforded only a small stipend for his work at Columbia University and his work in genetics and schizophrenia led to challenges in integration into the American psychiatric community. He continued working on his research in schizophrenia with studies of twin patients in New York hospitals and the Department of Mental Hygiene, mirroring the work of the Security Services of Nazi Germany. ${ }^{37}$ Although Kallmann continued his research in the new world, his most significant work on schizophrenia, published in 1938 while in the United States, was based on his studies in Germany. His work described siblings of schizophrenic patients as having a 10 times higher risk of schizophrenia than people with no family history.

Nevertheless, Kallmann enjoyed some career highs in New York when becoming president and cofounder of the American Society of Human Genetics in 1952 and director of the New York State Psychiatric Institute in 1955. The culmination of his research career saw 176 papers and 49 books and pamphlets written on schizophrenia, tuberculosis, and other genetic disorders before he died from cancer on May 12, 1965. Throughout his career in America, Kallmann continued to retain his stance on eugenics despite the controversial application of its merits in Nazi policies. Not only was this evident in speeches he made and articles he wrote on the matter, but also in his directorship of the American Eugenic Society in 1952 and from 1954 to 1965 . With his views on eugenics, Kallmann's research demonstrating the heritability of mental disorders was more formidably met with skepticism by psychiatrists and psychoanalysts. They were unconvinced of any genetic nature of disease traits such as schizophrenia and wary of the dangerous implications it would have given the recent Nazi atrocities. This viewpoint began to change however, shortly after Kallmann's death. ${ }^{37}$

\section{Conclusions}

The advent of World War II brought forth acts of heinous crimes against humanity, specifically targeting the Jews and other minorities in Germany and the Third Reich. Many Eastern European Jews sailed to new worlds, such as the United States. We portray the political scenario, personal choices, and professional achievements of three exceptional Jewish neuroscientists and physicians who emigrated to the United States. Many neuroscientists, neurologists, and neurosurgeons marveled at their brilliance in cerebral localization of clinical findings and the characterization of their respective eponymous syndromes: Josef Gerstmann, of Gerstmann syndrome; Adolf Wallenberg, of Wallenberg syndrome; and Franz Josef Kallmann, of Kallmann syndrome. Their astute ability to associate a constellation of topographically far-separated and diverse clinical signs in the human body to unifying complex focal anatomical substrates in the brain like the parietal lobe, lateral medulla, and olfactory system, respectively, 
during times of primordial brain imaging capabilities remains truly mystifying to physician-scientists to this day. The awe-inspiring stories of their escape from Nazi Germany and later challenges of integrating into the United States demonstrate the sheer passion, dedication, and grit of these three giants of neuroscience.

\section{References}

1. Badal J: Contribution to the study of psychic blindness. Arch Ophtalmol (Paris) 8:97-117, 1888

2. Benbassat CA: Kallmann syndrome: eugenics and the man behind the eponym. Rambam Maimonides Med J 7:e0015, 2016

3. Benton AL, Meyers R: An early description of the Gerstmann syndrome. Neurology 6:838-842, 1956

4. Dash PK, Raj DH: Biochemical and MRI findings of Kallmann's syndrome. BMJ Case Rep 2014:bcr2014207386, 2014

5. Davenport H: University of Michigan Surgeons 18501970: Who They Were and What They Did. Ann Arbor, MI: Historical Center for the Health Sciences, 1993, pp 137-141

6. Edsall DL, Tryon NC, Putnam TJ: The émigré physician in America, 1941: a report of the National Committee for Resettlement of Foreign Physicians. JAMA 117:1881-1888, 1941

7. Gershon ES: The historical context of Franz Kallmann and psychiatric genetics. Arch Psychiatr Nervenkr (1970) 229:273-276, 1981

8. Gerstmann J: Fingeragnosie. Eine umschriebene Störung der Orientierung am eigenen Körper. Wien Klin Wochenschr 40:1010-1012, 1924

9. Gerstmann J: Fingeragnosie und Agraphie-ein neues Syndrom. Z Gesamte Neurol Psychiatr 108:152-177, 1927

10. Gerstmann J: Über ein noch nicht beschriebenes Reflexphänomen bei einer Erkrankung des zerebellaren Systems. Wien Med Wochenschr 78:906-908, 1928

11. Gerstmann J: Zur lokaldiagnostischen Verwertbarkeit des Syndroms: Fingeragnosie, Rechts-Links-Störung, Agraphie, Akalkulie. Jahrbuch für Psychiatrie und Neurologie 48:135-143, 1932

12. Gerstmann J: Zur Symptomatologie der Hirnläsionen im Übergangsgebiet der unteren Parietal- und mittleren Occipitalwindung (Das Syndrom: Fingeragnosie, Rechts-LinksStörung, Agraphie, Akalkulie). Nervenarzt 3:691-695, 1930

13. Gerstmann J, Sträussler E: Zum Problemgebiet der Encephalomyelitis und der multiplen Sklerose. Zugleich ein Beitrag zur Frage des Verhältnisses zwischen klinischem und histologischem Befund. Archiv für Psychiatrie und Nervenkrankheiten (Berl) 93:182-211, 1931

14. Gerstmann J, Wagner-Jauregg J: Die Malariabehandlung der progressiven Paralyse, ed 2. Vienna: Springer, 1928

15. Goedert M: Oskar Fischer and the study of dementia. Brain 132:1102-1111, 2009

16. Gross CG: Hans-Lukas Teuber: a tribute. Cereb Cortex 4:451-454, 1994

17. Grzybowski A, Sak J: Lucja Frey (1889-1942): life destroyed by the Holocaust-on the 70th anniversary of her death. Clin Dermatol 30:355-359, 2012

18. Hassin GB: Otto Marburg, M.D. J Neuropathol Exp Neurol 8:240-250, 1949

19. Holdorff B: Emigrated neuroscientists from Berlin to North America. J Hist Neurosci 25:227-252, 2016

20. Holdorff B: Friedrich Heinrich Lewy (1885-1950) and his work. J Hist Neurosci 11:19-28, 2002

21. Jewish Virtual Library: Gdansk. Jewish Virtual Library. (https://www.jewishvirtuallibrary.org/gdansk) [Accessed July 15, 2019]
22. Kallmann F, Schönfeld W, Barrera S: The genetic aspects of primary eunuchoidism. Am J Ment Defic 48:203-236, 1944

23. Kernberg OF: The contributions of Edith Jacobson: and overview. J Am Psychoanal Assoc 27:793-819, 1979

24. Kilgour AJ, Williams HW: Walther Spielmeyer. Am J Psychiatry 92:255-257, 1935

25. Kinsbourne M, Warrington EK: A study of finger agnosia. Brain 85:47-66, 196222, 1962

26. Korer JR: Phenomenological psychology and schizophrenia as explored by Erwin Strauss. Br J Med Psychol 53:29-35, 1980

27. Kreutzberg GW, Klatzo I, Kleihues P: Oskar and Cécile Vogt, Lenin's brain and the bumble-bees of the Black Forest. Brain Pathol 2:363-371, 1992

28. Lange KW, Reichl S, Lange KM, Tucha L, Tucha O: The history of attention deficit hyperactivity disorder. Atten Defic Hyperact Disord 2:241-255, 2010

29. Ludmerer K: Time to Heal: American Medical Education from the Turn of the Century to the Era of Managed Care. New York: Oxford University Press, 2005

30. Maestre de San Juan A: Teratologia: falta total de los nervios olfactorios con anosmia en un individuo en quien existia una atrofia congénita de los testículos y miembro viril. EI Siglo Médico 3:211-221, 1856

31. Marcet A: History of a singular nervous or paralytic affection, attended with anomalous morbid sensations. J R Soc Med 2:215-233, 1811

32. Megargee GP (ed): The United States Holocaust Memorial Museum Encyclopedia of Camps and Ghettos, 19331945. Bloomington: Indiana University Press, 2009, Vol 3

33. Molnar M: Sigmund Freud (1856-1939): life and work. J Med Biogr 4:236-243, 1996

34. Naftolin F, Harris GW, Bobrow M: Effect of purified luteinizing hormone releasing factor on normal and hypogonadotrophic anosmic men. Nature 232:496-497, 1971

35. Paris J: Heinz Lehmann: A pioneer of modern psychiatry. Can J Psychiatry 44:441-442, 1999

36. Pekacka-Falkowska K, Pekacka AM: Władysław Sterling (1877-1943). J Neurol 266:1049-1050, 2019

37. Pow S, Stahnisch FW: Eugenics ideals, racial hygiene, and the emigration process of German-American neurogeneticist Franz Josef Kallmann (1897-1965). J Hist Neurosci 25:253274, 2016

38. Pow S, Stahnisch FW: Kurt Goldstein (1878-1965). J Neurol 261:1049-1050, 2014

39. Pytell T: The missing pieces of the puzzle: a reflection on the odd career of Viktor Frankl. J Contemp Hist 35:281-306, 2000

40. Rowland LP: The Legacy of Tracy J. Putnam and H. Houston Merritt: Modern Neurology in the United States. New York: Oxford University Press, 2008

41. Rusconi E, Pinel P, Dehaene S, Kleinschmidt A: The enigma of Gerstmann's syndrome revisited: a telling tale of the vicissitudes of neuropsychology. Brain 133:320-332, 2010

42. Sansone JM, Gatzke AM, Aslinia F, Rolak LA, Yale SH: Jules Tinel (1879-1952) and Paul Hoffman (1884-1962). Clin Med Res 4:85-89, 2006

43. Schütz W, Erker L, Rathkolb O, Sitte H: Anschluss 1938: aftermath on medicine and society. Wien Klin Wochenschr 130 (Suppl 5):279-341, 2018

44. Shoja MM, Tubbs RS, Loukas M, Ardalan MR: Adolf Wallenberg (1862-1949): physician and neuroanatomist. Childs Nerv Syst 24:979-981, 2008

45. Stahnisch FW: Forced migration as public relations process? Lothar B. Kalinowsky and the trans-atlantic transfer of electroconvulsive therapy. Can Bull Med Hist 33:385-417, 2016

46. Triarhou LC: Josef Gerstmann (1887-1969). J Neurol 255:614-615, 2008

47. United States Holocaust Memorial Museum: Introduc- 
tion to the Holocaust. Holocaust Encyclopedia. (https:// encyclopedia.ushmm.org/content/en/article/introduction-tothe-holocaust) [Accessed July 15, 2019]

48. Vanier MT: Niemann-Pick diseases. Handb Clin Neurol 113:1717-1721, 2013

49. Wallenberg A: Akute Bulbäraffektion (Embolie der Arteria cerebelli post inf sinistra). Archives fur Psychiatry 27:504540,1895

50. Wallenberg A: Anatomischer Befund in einen al "acute Bulbäraffection" (Embolie der Art. Cerebellr post. Sinstr.?) beschriebenen Falle. Arch Psych Nervenkrankh 34:923-959, 1901 (German)

51. Wallenberg A: Verschluss der arteria cerebelli inferior posterior dextra (mit Sektionbefund). Dtsch Z Nervenheilkd 73:189-212, 1922 (German)

52. Zeidman LA: Johannes C. Pompe, MD, hero of neuroscience: the man behind the syndrome. Muscle Nerve 46:134-138, 2012

53. Zeidman LA: Neuroscience in Nazi Europe part I: eugenics, human experimentation, and mass murder. Can J Neurol Sci 38:696-703, 2011

54. Zeidman LA: Neuroscience in Nazi Europe part II: resistance against the Third Reich. Can J Neurol Sci 38:826-838, 2011

55. Zeidman LA, Kondziella D: Neuroscience in Nazi Europe Part III: victims of the Third Reich. Can J Neurol Sci 39:729-746, 2012

56. Zeidman LA, Mohan L: Adolf Wallenberg: giant in neurology and refugee from Nazi Europe. J Hist Neurosci 23:3144, 2014
57. Zeidman LA, Ziller MG, Shevell M: "With a smile through tears": the uprooted career of the man behind Gerstmann syndrome. J Hist Neurosci 24:148-172, 2015

\section{Disclosures}

The authors report no conflict of interest concerning the materials or methods used in this study or the findings specified in this paper.

\section{Author Contributions}

Conception and design: S Manjila, Fana, Smith, Gable. Acquisition of data: all authors. Analysis and interpretation of data: $S$ Manjila, Fana, Smith. Drafting the article: Fana, Smith, Gable, S Manjila. Critically revising the article: S Manjila, Fana, Smith, Gable. Reviewed submitted version of manuscript: S Manjila, Fana, Smith, Gable. Approved the final version of the manuscript on behalf of all authors: S Manjila. Study supervision: S Manjila.

\section{Correspondence}

Sunil Manjila: McLaren Bay Region Hospital, Bay City, MI. sunil. manjila@gmail.com. 